Prepared in cooperation with the Village of Endicott, New York

\title{
Hydrogeology and Water Quality of the Nanticoke Creek Stratified-Drift Aquifer, near Endicott, New York
}

Scientific Investigations Report 2014-5063 
Cover. Endicott Water Works, 1926, from the photo archive of the Village of Endicott, New York. 


\section{Hydrogeology and Water Quality of the Nanticoke Creek Stratified-Drift Aquifer, near Endicott, New York}

By Elizabeth A. Kreitinger and William M. Kappel

Prepared in cooperation with the Village of Endicott, New York

Scientific Investigations Report 2014-5063 


\title{
U.S. Department of the Interior SALLY JEWELL, Secretary
}

\section{U.S. Geological Survey Suzette M. Kimball, Acting Director}

\author{
U.S. Geological Survey, Reston, Virginia: 2014
}

For more information on the USGS - the Federal source for science about the Earth, its natural and living resources, natural hazards, and the environment, visit http://www.usgs.gov or call 1-888-ASK-USGS.

For an overview of USGS information products, including maps, imagery, and publications, visit http://www.usgs.gov/pubprod

To order this and other USGS information products, visit http://store.usgs.gov

Any use of trade, firm, or product names is for descriptive purposes only and does not imply endorsement by the U.S. Government.

Although this information product, for the most part, is in the public domain, it also may contain copyrighted materials as noted in the text. Permission to reproduce copyrighted items must be secured from the copyright owner.

Suggested citation:

Kreitinger, E.A., and Kappel, W.M., 2014, Hydrogeology and water quality of the Nanticoke Creek stratified-drift aquifer, near Endicott, New York: U.S. Geological Survey Scientific Investigations Report 2014-5063, 19 p. plus appendixes, $h$ ttp://dx.doi.org/10.3133/sir20145063.

ISSN 2328-0328 (online) 


\section{Contents}

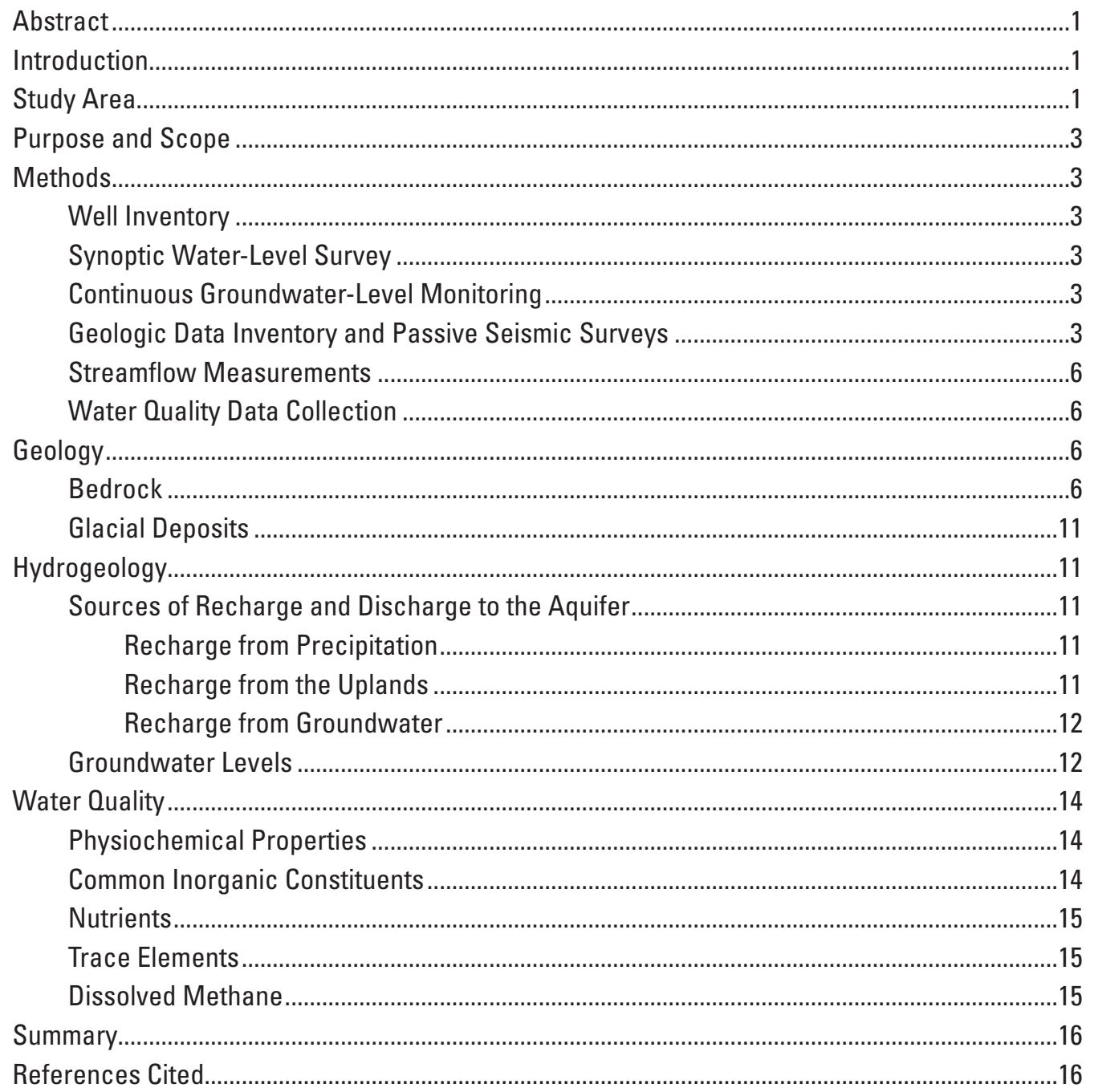

Appendix 1. Record of Wells and Test Holes Used in the Nanticoke Creek Stratified-Drift Aquifer Study, Broome County, New York ....................................................................19

Appendix 2. Results of Seepage Measurements and Subbasin Data for Nanticoke Creek and its Major Tributaries, Broome County, New York........................................................19

Appendix 3. Water-Quality Data for Four Surface-Water Sites and Three Groundwater Wells in the Nanticoke Creek Valley, Broome County, New York.....................................19

Appendix 4. Historic Water-Quality Data for Nanticoke Creek, Broome County, New York........19

Appendix 5. Susquehanna River Basin Commission Real-Time and Periodic Water-Quality Data for Nanticoke Creek near Maine, New York...........................................................19

Appendix 6. Water-Quality Data from a Greenhouse Supply Well, 1991, 2001, and 2011, and a Residential House Well, 2011, near Union Center, New York 


\section{Figures}

1. Map showing location of Nanticoke Creek watershed, boundary of the stratifieddrift aquifer, and map sections $A$, (lower Nanticoke Creek) and $B$, (upper Nanticoke Creek), near Endicott, Broome County, New York.

2. Map showing groundwater-level, surface-water-stage gage, and water-quality data-collection locations, in the stratified-drift aquifer, Nanticoke Creek valley near Endicott, Broome County, New York

3. Map of the altitude of the bedrock surface beneath the stratified-drift aquifer, Nanticoke Creek valley near Endicott, Broome County, New York

4. Map of surficial geology of the stratified-drift aquifer, Nanticoke Creek valley near Endicott, Broome County, New York.

5. Geologic sections $A-A^{\prime}, B-B^{\prime}$, and $C-C^{\prime}$ in the Nanticoke Creek valley, Broome County, New York.

6. Graphs showing monitored groundwater levels in the Nanticoke Creek stratifieddrift aquifer, water levels in Nanticoke Creek at Union Center, New York, and daily precipitation from the Binghamton Regional airport, July 2012 to July 2013. 


\section{Conversion Factors and Datum}

Inch/Pound to SI

\begin{tabular}{|c|c|c|}
\hline Multiply & By & To obtain \\
\hline \multicolumn{3}{|c|}{ Length } \\
\hline inch (in.) & 2.54 & centimeter $(\mathrm{cm})$ \\
\hline inch (in.) & 25.4 & millimeter $(\mathrm{mm})$ \\
\hline foot $(\mathrm{ft})$ & 0.3048 & meter $(\mathrm{m})$ \\
\hline mile (mi) & 1.609 & kilometer $(\mathrm{km})$ \\
\hline yard (yd) & 0.9144 & meter $(\mathrm{m})$ \\
\hline \multicolumn{3}{|c|}{ Area } \\
\hline acre & 4,047 & square meter $\left(\mathrm{m}^{2}\right)$ \\
\hline acre & 0.4047 & hectare (ha) \\
\hline acre & 0.004047 & square kilometer $\left(\mathrm{km}^{2}\right)$ \\
\hline square foot $\left(\mathrm{ft}^{2}\right)$ & 929.0 & square centimeter $\left(\mathrm{cm}^{2}\right)$ \\
\hline section (640 acres or 1 square mile) & 259.0 & square hectometer $\left(\mathrm{hm}^{2}\right)$ \\
\hline square mile $\left(\mathrm{mi}^{2}\right)$ & 259.0 & hectare (ha) \\
\hline square mile $\left(\mathrm{mi}^{2}\right)$ & 2.590 & square kilometer $\left(\mathrm{km}^{2}\right)$ \\
\hline \multicolumn{3}{|c|}{ Volume } \\
\hline gallon (gal) & 3.785 & liter $(\mathrm{L})$ \\
\hline gallon (gal) & 0.003785 & cubic meter $\left(\mathrm{m}^{3}\right)$ \\
\hline gallon (gal) & 3.785 & cubic decimeter $\left(\mathrm{dm}^{3}\right)$ \\
\hline million gallons (Mgal) & 3,785 & cubic meter $\left(\mathrm{m}^{3}\right)$ \\
\hline acre-foot (acre-ft) & 1,233 & cubic meter $\left(\mathrm{m}^{3}\right)$ \\
\hline acre-foot (acre-ft) & 0.001233 & cubic hectometer $\left(\mathrm{hm}^{3}\right)$ \\
\hline \multicolumn{3}{|c|}{ Flow rate } \\
\hline foot per second $(\mathrm{ft} / \mathrm{s})$ & 0.3048 & meter per second $(\mathrm{m} / \mathrm{s})$ \\
\hline foot per hour (ft/hr) & 0.3048 & meter per hour $(\mathrm{m} / \mathrm{hr})$ \\
\hline $\begin{array}{l}\text { cubic foot per second per square } \\
\text { mile }\left[\left(\mathrm{ft}^{3} / \mathrm{s}\right) / \mathrm{mi}^{2}\right]\end{array}$ & 0.01093 & $\begin{array}{l}\text { cubic meter per second per square } \\
\text { kilometer }\left[\left(\mathrm{m}^{3} / \mathrm{s}\right) / \mathrm{km}^{2}\right]\end{array}$ \\
\hline cubic foot per day $\left(\mathrm{ft}^{3} / \mathrm{d}\right)$ & 0.02832 & cubic meter per day $\left(\mathrm{m}^{3} / \mathrm{d}\right)$ \\
\hline inch per year (in/yr) & 25.4 & millimeter per year (mm/yr) \\
\hline mile per hour $(\mathrm{mi} / \mathrm{h})$ & 1.609 & kilometer per hour $(\mathrm{km} / \mathrm{h})$ \\
\hline inch per year per foot $[(\mathrm{in} / \mathrm{yr}) / \mathrm{ft}]$ & 83.33 & $\begin{array}{l}\text { millimeter per year per meter } \\
\qquad[(\mathrm{mm} / \mathrm{yr}) / \mathrm{m}]\end{array}$ \\
\hline
\end{tabular}

Temperature in degrees Celsius $\left({ }^{\circ} \mathrm{C}\right)$ may be converted to degrees Fahrenheit $\left({ }^{\circ} \mathrm{F}\right)$ as follows: ${ }^{\circ} \mathrm{F}=\left(1.8 \times{ }^{\circ} \mathrm{C}\right)+32$

Temperature in degrees Fahrenheit $\left({ }^{\circ} \mathrm{F}\right)$ may be converted to degrees Celsius $\left({ }^{\circ} \mathrm{C}\right)$ as follows: ${ }^{\circ} \mathrm{C}=\left({ }^{\circ} \mathrm{F}-32\right) / 1.8$

Vertical coordinate information is referenced to the North American Vertical Datum of 1988 (NAVD 88).

Horizontal coordinate information is referenced to the North American Datum of 1983 (NAD 83).

Altitude, as used in this report, refers to distance above the vertical datum. 


\title{
Hydrogeology and Water Quality of the Nanticoke Creek Stratified-Drift Aquifer, near Endicott, New York
}

\author{
By Elizabeth A. Kreitinger and William M. Kappel
}

\section{Abstract}

The Village of Endicott, New York, is seeking an alternate source of public drinking water with the potential to supplement their current supply, which requires treatment due to legacy contamination. The southerly-draining Nanticoke Creek valley, located north of the village, was identified as a potential water source and the local stratified-drift (valley fill) aquifer was investigated to determine its hydrogeologic and water-quality characteristics.

Nanticoke Creek and its aquifer extend from the hamlet of Glen Aubrey, N.Y., to the village of Endicott, a distance of about 15 miles, where it joins the Susquehanna River and its aquifer. The glacial sediments that comprise the stratified-drift aquifer vary in thickness and are generally underlain by glacial till over Devonian-aged shale and siltstone.

Groundwater is more plentiful in the northern part of the aquifer where sand and gravel deposits are generally more permeable than in the southern part of the aquifer where less-permeable unconsolidated deposits are found. Generally there is enough groundwater to supply most homeowner wells and in some cases, supply small public-water systems such as schools, mobile-home parks, and small commercial/industrial facilities. The aquifer is recharged by precipitation, runoff, and tributary streams. Most tributary streams flowing across alluvial deposits lose water to the aquifer as they flow off of their bedrock-lined channels and into the more permeable alluvial deposits at the edges of the valley.

The quality of both surface water and groundwater is generally good. Some water wells do have water-quality issues related to natural constituents (manganese and iron) and several homeowners noted either the smell and (or) taste of hydrogen sulfide in their drinking water. Dissolved methane concentrations from five drinking-water wells were well below the potentially explosive value of 28 milligrams per liter. Samples from surface and groundwater met nearly all State and Federal water-quality standards for common ion and nutrient concentrations with the exception of manganese, which is common in central New York where water sourced from shale rock or glacial sediments derived from shale bedrock naturally develops higher manganese concentrations. One shallow dug well also had elevated sodium and chloride concentrations that are likely sourced from road salt runoff from two nearby roads.

\section{Introduction}

The Village of Endicott relies on wells that supply groundwater from a sand and gravel aquifer within the Susquehanna River valley to which the Nanticoke Creek and its aquifer drain. Contamination in and near the village of Endicott has been documented by U.S. Environmental Protection Agency (EPA) and the New York Department of Environmental Conservation (NYDEC). Currently (2014), the Village of Endicott pumps and treats its water supply from a number of wells in the Susquehanna River aquifer within the village limits. The village also has the option to purchase water from nearby municipalities if needed. The village is interested in locating alternative sites where municipal supply wells could be developed and protecting those sites from future water quality degradation. For this reason, Endicott is exploring the potential for water-supply well development in Nanticoke Creek valley north of the village, To assist with this effort, the U.S. Geological Survey (USGS), in cooperation with the Village of Endicott, investigated the hydrogeologic and water-quality characteristics of the Nanticoke Creek stratified-drift aquifer. Results from the study will enhance scientific knowledge of stratified-drift aquifers and can be used to improve understanding of groundwater availability for this type of aquifer in the northeastern United States.

\section{Study Area}

Nanticoke Creek is the closest tributary valley to the village with no significant documented legacy of contamination. The Nanticoke valley contains a narrow stratified-drift aquifer that is less than a half-mile wide, 15 miles long, and drains to the south. This aquifer extent is from north of Glen Aubrey, New York, southward through the hamlets of Maine, Union Center, and West Corners before reaching the Village of Endicott. The stratified-drift aquifer in the Nanticoke Creek watershed encompasses about 17 square miles, within the 111 square mile Nanticoke Creek watershed (fig. 1). 


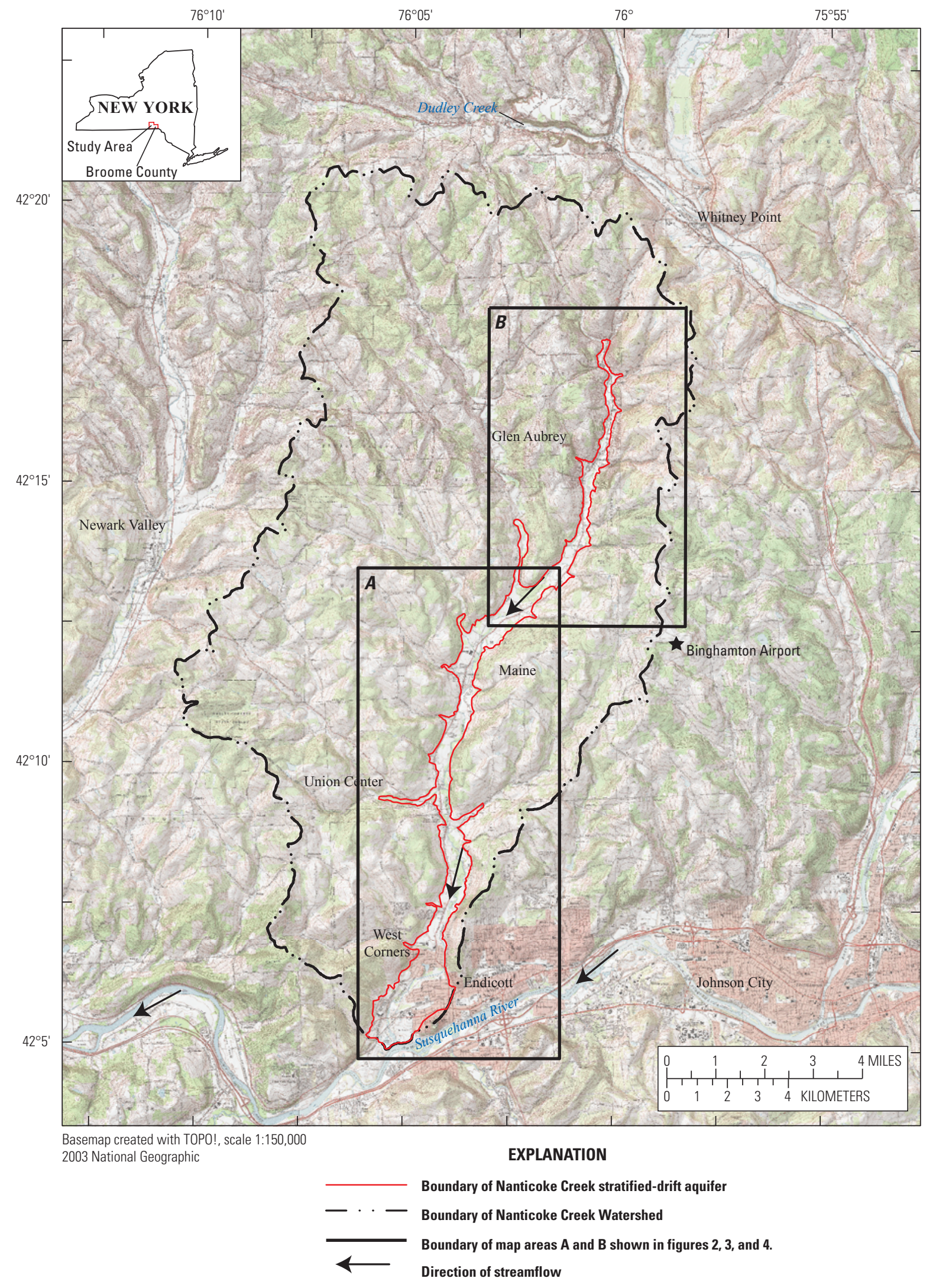

Figure 1. Location of Nanticoke Creek watershed, boundary of the stratified-drift aquifer, and map sections $A$, (lower Nanticoke Creek) and B, (upper Nanticoke Creek), near Endicott, Broome County, New York. 


\section{Purpose and Scope}

The purpose of this study is to determine the hydrogeology and water quality of the stratified-drift aquifer in the Nanticoke Creek valley. This report includes information on the: (1) boundary of the aquifer and the hydrogeologic units within the boundary, (2) hydraulic characteristics of the aquifer, (3) extent of groundwater/surface-water interaction, (4) the water levels within the aquifer and the direction of groundwater flow, and (5) the general water quality of Nanticoke Creek and its underlying aquifer.

\section{Methods}

Various types of data were collected to provide the basis for interpreting the hydrogeology and water quality in the Nanticoke Creek valley. The field methodologies employed throughout this study followed standard USGS guidelines and technical manuals, and all field data used in this report were collected by USGS personnel.

\section{Well Inventory}

Well records were collected from several sources, including the USGS Ground-Water Site Inventory (GWSI) database, NYSDEC Water-Well Reporting Program, and the Broome County Health Department. The most complete well records were provided by the NYSDEC Water-Well Reporting Program, which was implemented in 2000 to collect information on newly drilled wells in New York from licensed water-well drillers. These data include well location (fig. 2) and depth, water level, sediment lithology, and well yield. The Broome County Health Department identified public-supply wells (such as mobile home parks, schools, and restaurants), and the Village of Endicott assisted in gathering background information throughout the project.

\section{Synoptic Water-Level Survey}

For the synoptic water-level survey, selected homeowners, commercial facilities, and institutions were sent letters describing the project and requesting permission to measure the water level in their well. Groundwater levels were measured in 21 wells on or adjacent to the Nanticoke Creek valley floor on October 17, 2012, during a period that seasonally represents lower water-table conditions in the region. Land-surface altitudes at wells were derived from USGS 1:24,000 topographic maps and 10-meter digital elevation model (DEM) data sets (NAVD 88) (National Elevation Dataset, at http://ned.usgs.gov/). Water levels were measured from the top of the well casing (TOC) and the height of the well above land surface (stick-up) was noted at each location. Casing stick-up values were subtracted from tape down measurements and the computed groundwater levels were adjusted to the nearest foot relative to NAVD 88 (Appendix Data Table 1 at http://pubs.usgs.gov/sir/2014/5063/ appendix/sir2014-5063_appendix_table1-1.xlsx). Where data were non-existent, generally in tributary valleys, the elevation of the stream where it crossed selected land-surface elevation contours were used to approximate groundwater elevations in these areas.

\section{Continuous Groundwater-Level Monitoring}

Water levels were monitored in three wells in the Nanticoke Creek valley using sealed pressure transducers which recorded groundwater levels every four hours. One well, BM 778, in unconsolidated materials was monitored at the Maine-Endwell school bus garage (Maine, N.Y.) - the well is completed in unconsolidated material and is 140-feet deep. A second well, BM 785, in the village of Union Center, N.Y., is 80-feet deep and is cased through unconsolidated materials and completed in bedrock. The third well BM 787, located between Union Center and West Corners, N.Y., near Nanticoke Creek, is believed to be finished in unconsolidated materials near bedrock and is approximately 65-feet deep (fig. 2).

The water level of Nanticoke Creek was also monitored with a transducer located at the Nanticoke Road bridge over Nanticoke Creek (station number 01513790) in Union Center, N.Y. (fig. 2). This transducer was used to measure streamlevel changes due to precipitation and runoff in the watershed, and how reactive streamflow was to precipitation. Finally, a barometric transducer, used to compensate for barometric pressure changes in the well and stream transducer water levels was maintained in the village of Endicott Department of Public Works office.

\section{Geologic Data Inventory and Passive Seismic Surveys}

Regional-scale (scale 1:250,000), surficial, glacialdeposit maps by Muller and Cadwell (1986) were modified for this study to construct a surficial-deposits map at a scale of 1:24,000 (fig. 3) and were enhanced using field checking, landform interpretations from topographic maps, orthophotos, and SSURGO digital soil-survey data (U.S. Department of Agriculture, 2008).

Sources of well and test-boring data include previous USGS groundwater studies such as Randall (1972), Brown and Ferris (1946), Martin and Shumaker (1968), the USGS National Water Information System (NWIS), the NYSDEC Water Well Drillers Registration Program (water well records from 2000 to 2012), and the New York State Department of Transportation (borehole logs for road and bridge construction). All records collected for this study were entered into the USGS Groundwater Site Inventory (GWSI) computer database and are accessible at http://waterdata.usgs.gov/ny/ nwis/inventory. Locations of wells, test-borings, and passive seismic data are shown on figure 3 . All of these data were used 
$\boldsymbol{A}$

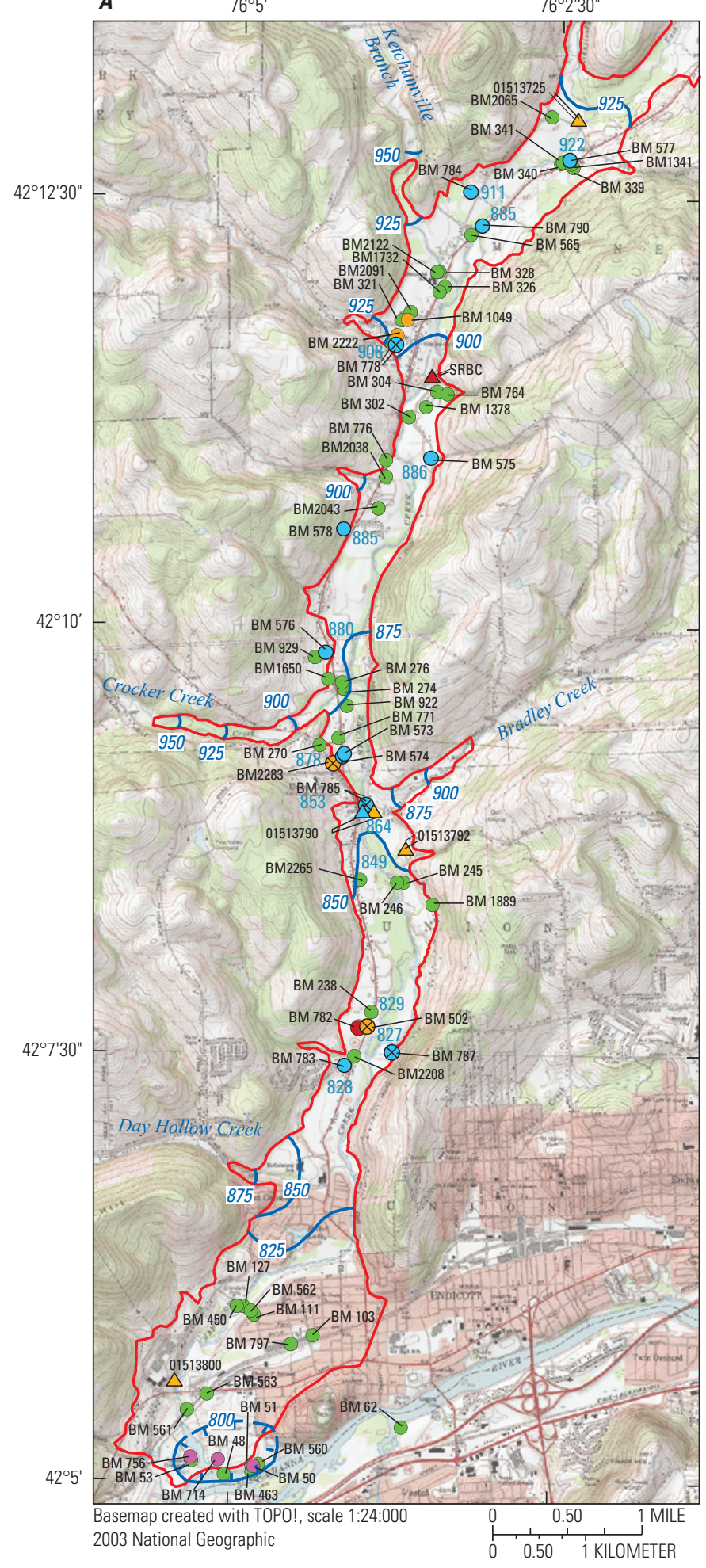

B

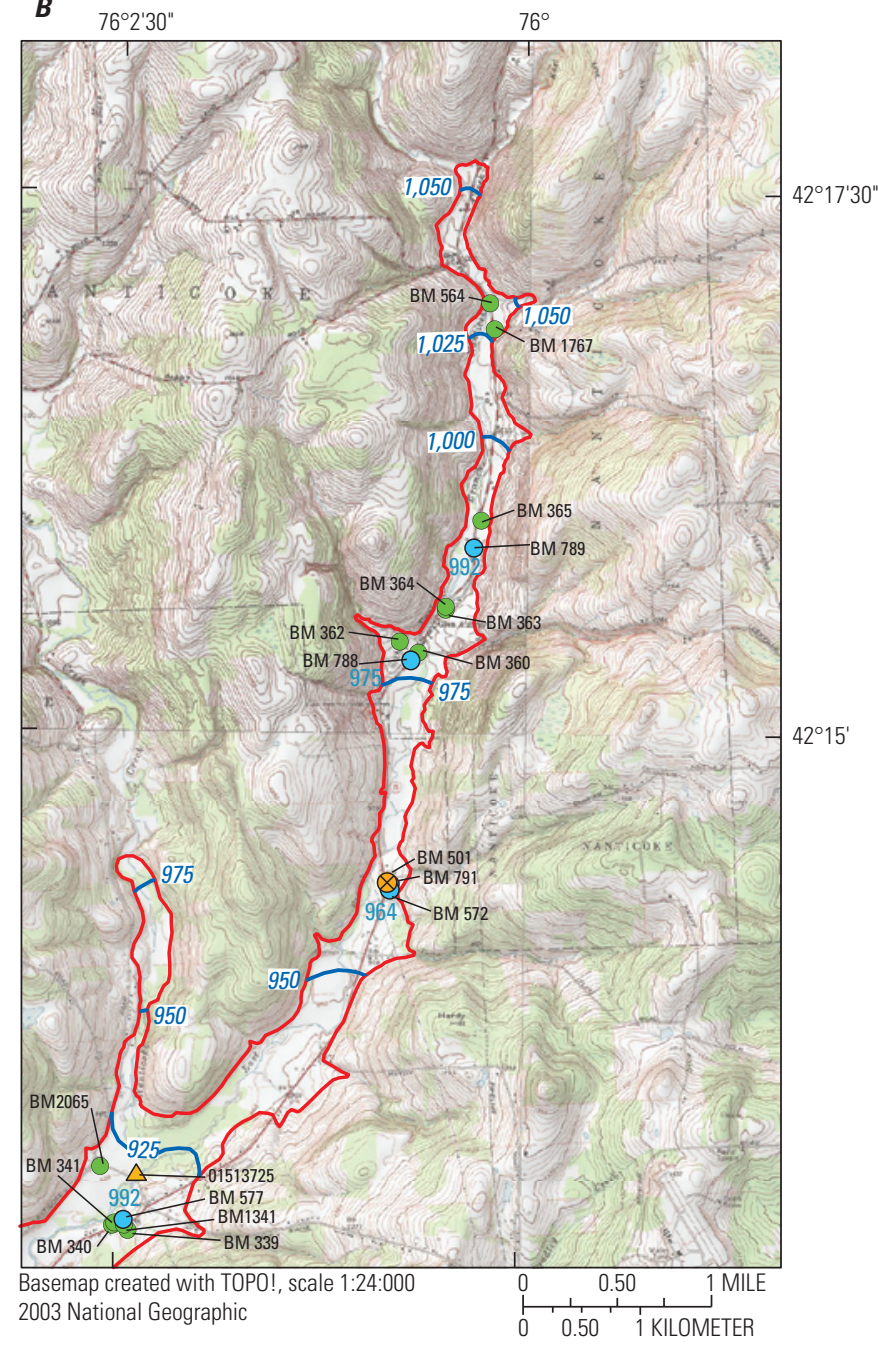

EXPLANATION

Boundary of Nanticoke Creek Stratified-Drift Aquifer

— 925 Water-table contour-Shows approximate altitude of groundwater table on October 17, 2012, in feet above North American Vertical Datum of 1988 (NAVD). Interval is 25 feet. (Hatchered contour indicates drawdown)

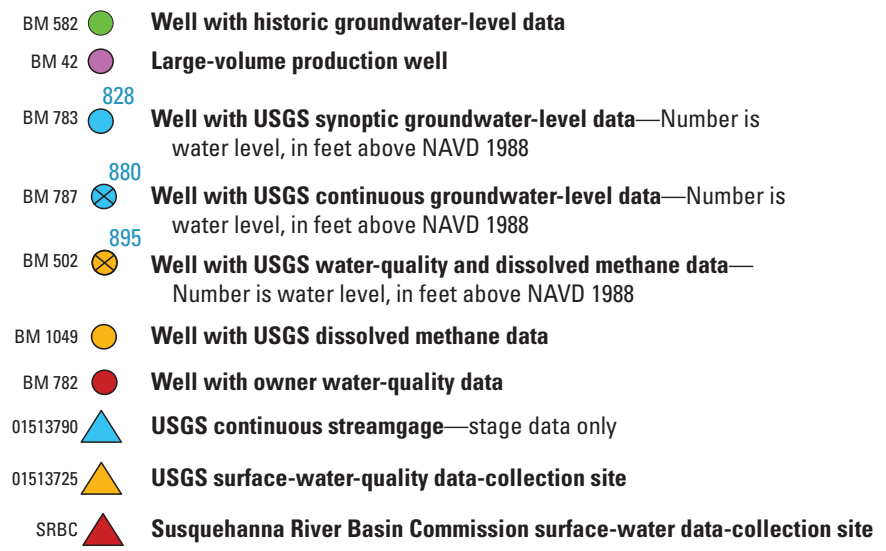

Figure 2. Groundwater-level, surface-water-stage gage, and water-quality data-collection locations, in the stratified-drift aquifer, Nanticoke Creek valley near Endicott, Broome County, New York. (Location of wells in data-collection network have U.S. Geological Survey (USGS) Broome County [BM\#\#\#] well numbers.) 

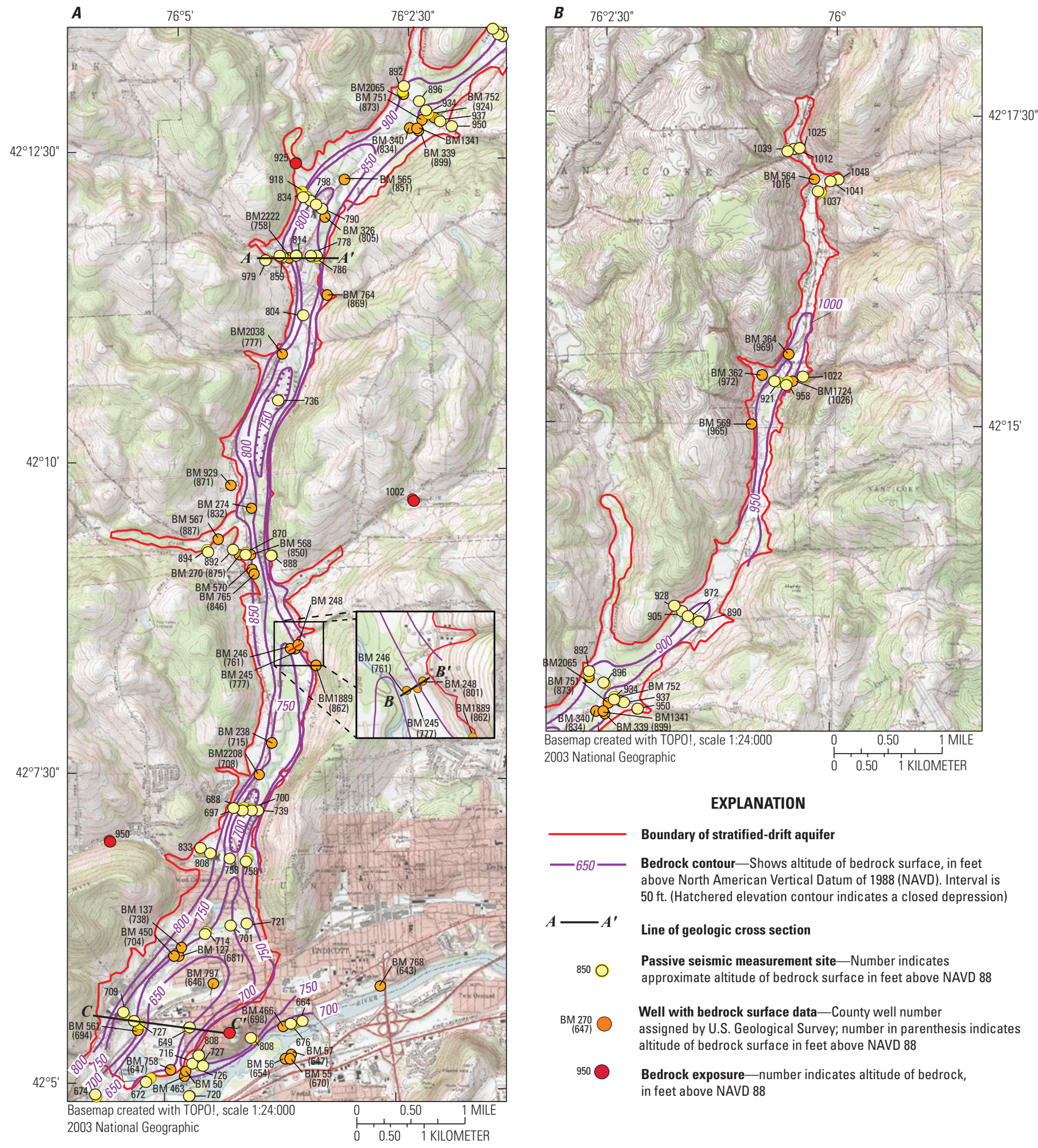

\section{EXPLANATION}

Boundary of stratified-drift aquifer

- 650 B Bedrock contour-Shows altitude of bedrock surface, in feet above North American Vertical Datum of 1988 (NAVD). Interval is $50 \mathrm{ft}$. (Hatchered elevation contour indicates a closed depression)

$A-A^{\prime} \quad$ Line of geologic cross section

Passive seismic measurement site-Number indicates approximate altitude of bedrock surface in feet above NAVD 88

BM 270 Well with bedrock surface data - County well number ${ }_{(647)}{ }_{270}$ assigned by U.S. Geological Survey; number in parenthesis indicates altitude of bedrock surface in feet above NAVD 88

950 Bedrock exposure-number indicates altitude of bedrock, in feet above NAVD 88

Figure 3. The altitude of the bedrock surface beneath the stratified-drift aquifer, Nanticoke Creek valley near Endicott, Broome County, New York. (Location of areas $A$ and $B$ shown in figure 1; geologic cross sections shown in figure 5.) 
Hydrogeology and Water Quality of the Nanticoke Creek Stratified-Drift Aquifer, near Endicott, New York

to define the surficial extent of the Nanticoke Creek aquifer (fig. 4), depict aquifer stratigraphy in three geologic sections (fig. 5), and determine the bedrock surface configuration in the Nanticoke Creek valley (fig. 3).

Subsurface data including well- and test-drilling records and passive seismic surveys were also used for interpretation. The passive seismic (also called horizontal-to-vertical (H/V) ambient-noise seismic) survey technique is a geophysical method used to estimate the thickness of sediments over bedrock as described in detail in Lane and others (2008). Passive seismic data were collected at 59 locations to create 11 full or partial cross-valley geologic sections in the Nanticoke Creek valley. Three of these geologic sections had enough stratigraphic materials information to create both a bedrock profile and an indication of glacial materials that filled the valley in these sections (fig. 5).

\section{Streamflow Measurements}

Streamflow (gain or loss) measurements were made at three sites along Nanticoke Creek and four major tributaries to quantify the amount of recharge to, or discharge from, the valley-fill aquifer. On July 17, 2012, streamflow measurements were made on Nanticoke Creek at: (1) Ames Road (Station number-01513725), (2) Union Center, N.Y. (01513790), and (3) Endicott, N.Y. (01513800), as well as a streamflow measurement on the Bradley Creek at Nanticoke Road (01513792) during early summer low-flow conditions. Stream water-quality samples were also collected at the same time at these four sites (fig. 2).

On August 7, 2012, streamflow measurements along (1) the Ketchumville Branch, (2) Crocker Creek, (3) Bradley Creek, and (4) Day Hollow Creek (fig. 2) were made during summer low-flow conditions. This information was used to determine if major tributaries to Nanticoke Creek were gaining water from, or losing water to the aquifer. Discharge measurements were made with either a Price AA or Pygmy current meter in accordance with USGS standards and methods (Rantz and others, 1982). In several cases, the flow was so low that volumetric discharges were determined by concentrating the flow to one point and collecting it into a calibrated 5 gallon bucket over a set period of time to determine the stream discharge in cubic feet per second $\left(\mathrm{ft}^{3} / \mathrm{s}\right)$. All measurements were then standardized by developing a flow per unit area at each measurement location - cubic feet per second per square mile $\left(\mathrm{ft}^{3} / \mathrm{s} / \mathrm{mi}^{2}\right)$. Measurements were rated good to fair based on Rantz and others (1982).

\section{Water Quality Data Collection}

Water samples were collected by the USGS and processed at each stream location or from each well using methods described in USGS manuals for the collection of water-quality data (U.S. Geological Survey, variously dated). Stream samples were collected using an equal-width increment protocol at each stream site while groundwater samples were collected at an untreated tap, typically before or just after a pressure tank and before any filtration or water softening. All water samples were analyzed in the field for physical properties and dissolved oxygen and shipped overnight to the USGS National Water Quality Laboratory (NWQL) in Denver, Colorado, for analysis for major ions, nutrients, metals and trace constituents. Dissolved gas analyses were only performed on groundwater samples and these samples were analyzed by USGS Dissolved Gas Laboratory in Reston, Virginia.

The analyses for physical properties and dissolved gases were performed on unfiltered water samples to obtain total concentrations. Description of the analytical methods used for all constituents except the dissolved gases are available through the U.S. Geological Survey (2012a); the methods for determination of dissolved gases in water are described by the U.S. Geological Survey (2012b). The analytical results are available through the USGS National Water Information System (U.S. Geological Survey, 2012c).

\section{Geology}

The Nanticoke Creek valley is underlain by sedimentary bedrock of Upper Devonian age that consists of shales and siltstones in the higher elevations in the northern part of the valley and primarily shales in the southern part. The bedrock is overlain by unconsolidated glacial materials (sand and gravel, clay and silt, and till), and more recent alluvium (sand and gravel) and wetland deposits.

\section{Bedrock}

Bedrock that underlies the valley and crops out at land surface on the surrounding hillsides consists of Upper Devonian Sonyea Group shales and siltstones in the northern and central uplands of the watershed and West Falls Group shales are present further south in the lower Nanticoke Creek watershed. These sediments were deposited in seas 374-360 million years ago (Rickard and Fisher, 1970). Bedrock crops out at land surface along the flanks of many of the valleys and on the hilltops. The regional dip of the strata is southward at 40 to 60 feet per mile ( $\mathrm{ft} / \mathrm{mi})$; however, the strata may be warped into shallow folds which result in local variations in direction and steepness of dip.

Eleven passive seismic cross-valley surveys were conducted to estimate the depth to bedrock in the Nanticoke Creek valley (fig. 3). The deepest passive seismic bedrock measurement in the northern end of the valley was about 38 feet (ft), and about $190 \mathrm{ft}$ near the southern end where the Nanticoke and Susquehanna valleys join. The bedrock floor of the Nanticoke Creek valley exhibits a southward dipping surface, but at several locations, deeper 'depressions' were documented on the valley floor likely due to dynamic glacial ice flow, especially in the narrower parts of the valley (fig. 3). 

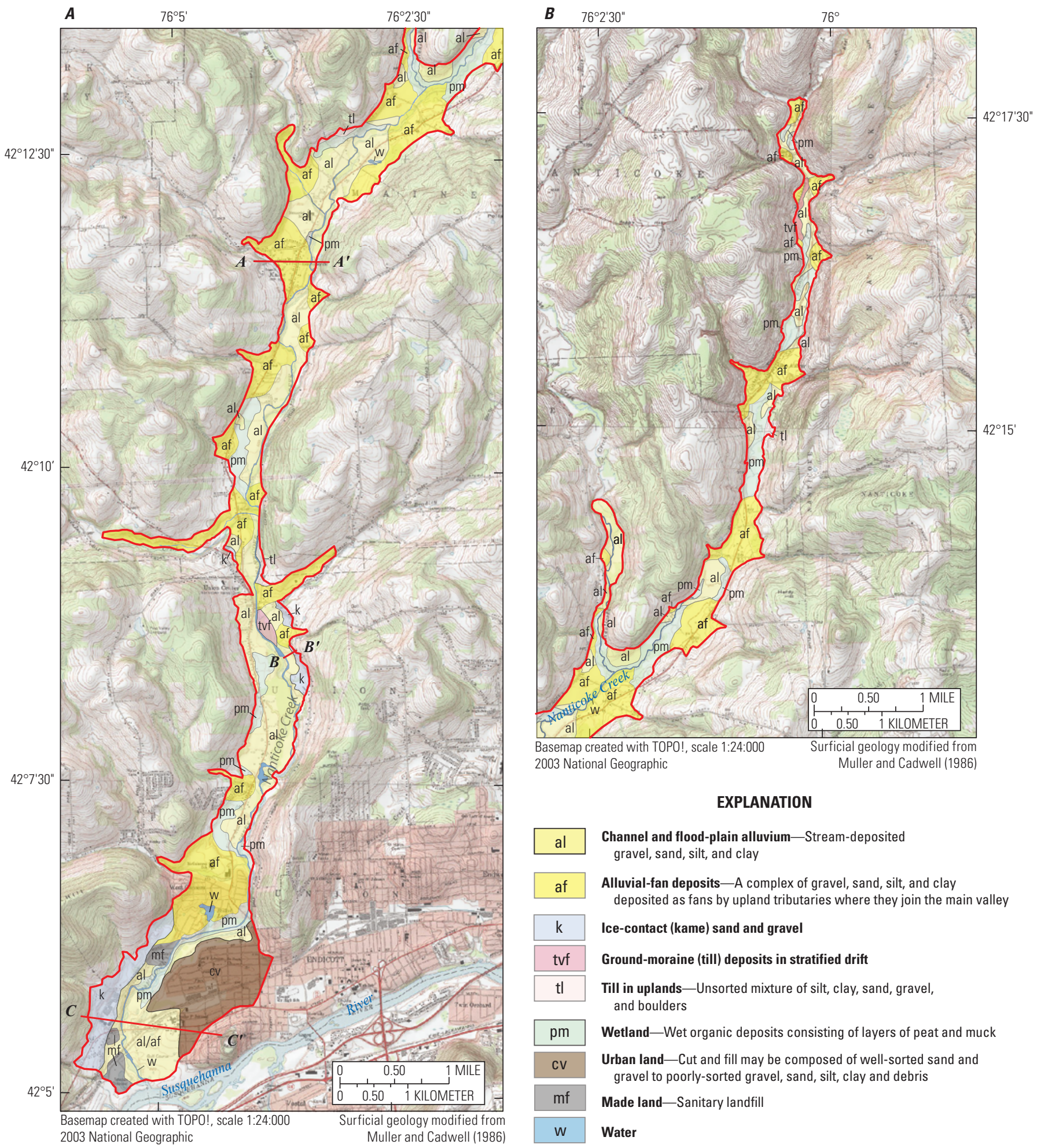

al Channel and flood-plain alluvium-Stream-deposited gravel, sand, silt, and clay

af Alluvial-fan deposits-A complex of gravel, sand, silt, and clay deposited as fans by upland tributaries where they join the main valley

\begin{tabular}{|c|c|}
\hline k & Ice-contact (kame) sand and gravel \\
\hline tvf & Ground-moraine (till) deposits in stratified drift \\
\hline $\mathrm{tl}$ & Till in uplands-Unsorted mixture of silt, clay, sand, gravel, \\
\hline
\end{tabular}

pm Wetland-Wet organic deposits consisting of layers of peat and muck

CV Urban land-Cut and fill may be composed of well-sorted sand and gravel to poorly-sorted gravel, sand, silt, clay and debris

mf Made land-Sanitary landfill

W Water

Boundary of stratified-drift aquifer

$A-A^{\prime}$ Line of geologic section

Figure 4. Surficial geology of the stratified-drift aquifer, Nanticoke Creek valley near Endicott, Broome County, New York. (Location of areas $A$ and $B$ shown in figure 1; geologic sections shown in figure 5.) 


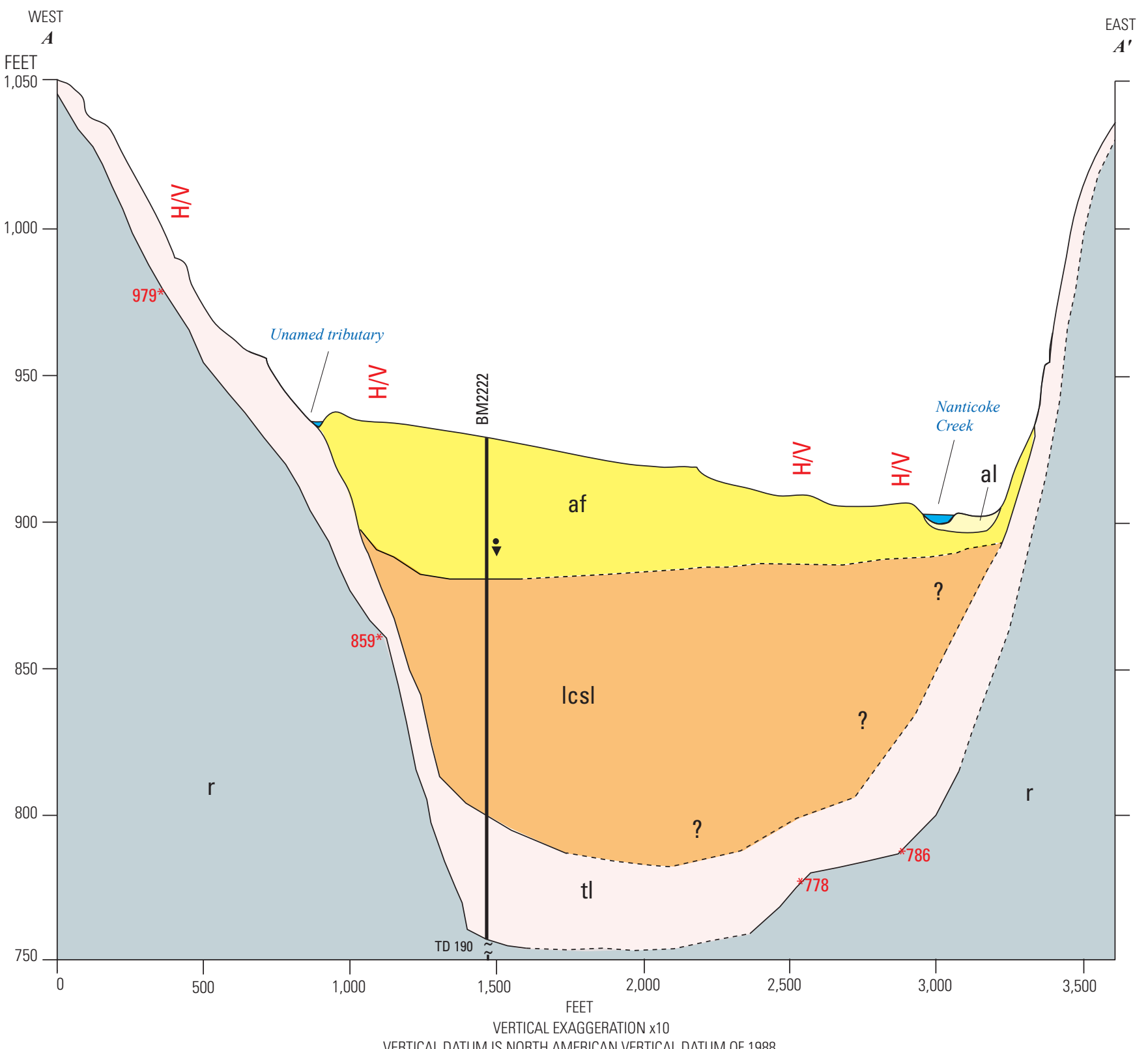

VERTICAL DATUM IS NORTH AMERICAN VERTICAL DATUM OF 1988

\section{EXPLANATION}

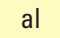

Channel and flood-plain alluvium—Gravel, sand, and silt deposited by recent streams. Deposits are found beneath flood plains, on low terraces, and in stream channels

af Alluvial-fan deposits-Sand and gravel with some silt deposited as fans by upland tributaries where they join the main valley. May form local unconfined aquifers

IcsI Clay and silt-Fine-grained sediments that were deposited in former glacial and postglacial lakes; some deposits settled in small separate basins

tl

Ground-moraine (till) deposits-Consists of subangular

to angular clasts (pebbles to boulders) derived in large part from local bedrock that became embedded in a fine-grained matrix consisting of clay, silt, and fine sand

Bedrock-Devonian-age shale, siltstone, and sandstone

\section{$\gtrless \quad$ Passive (horizontal-to-vertical ambient-noise) seismic measurement- Asterisk denotes location, number is bedrock altitude, in feet above North American Datum of 1988 (NAVD 88)}

BM2222 Well with lithologic log and identifier-Broome County well number

$\perp \quad$ (assigned by U.S. Geological Survey); TD and number indicates total depth of well in feet

\section{Geologic Contacts}

- Accurately to approximately located

-..... Inferred

??? Unknown

- Water level-Static water level in well

Figure 5. Geologic sections $A-A^{\prime}, B-B^{\prime}$, and $C-C^{\prime}$ in the Nanticoke Creek valley, Broome County, New York. (Section lines shown on figure 4.) 


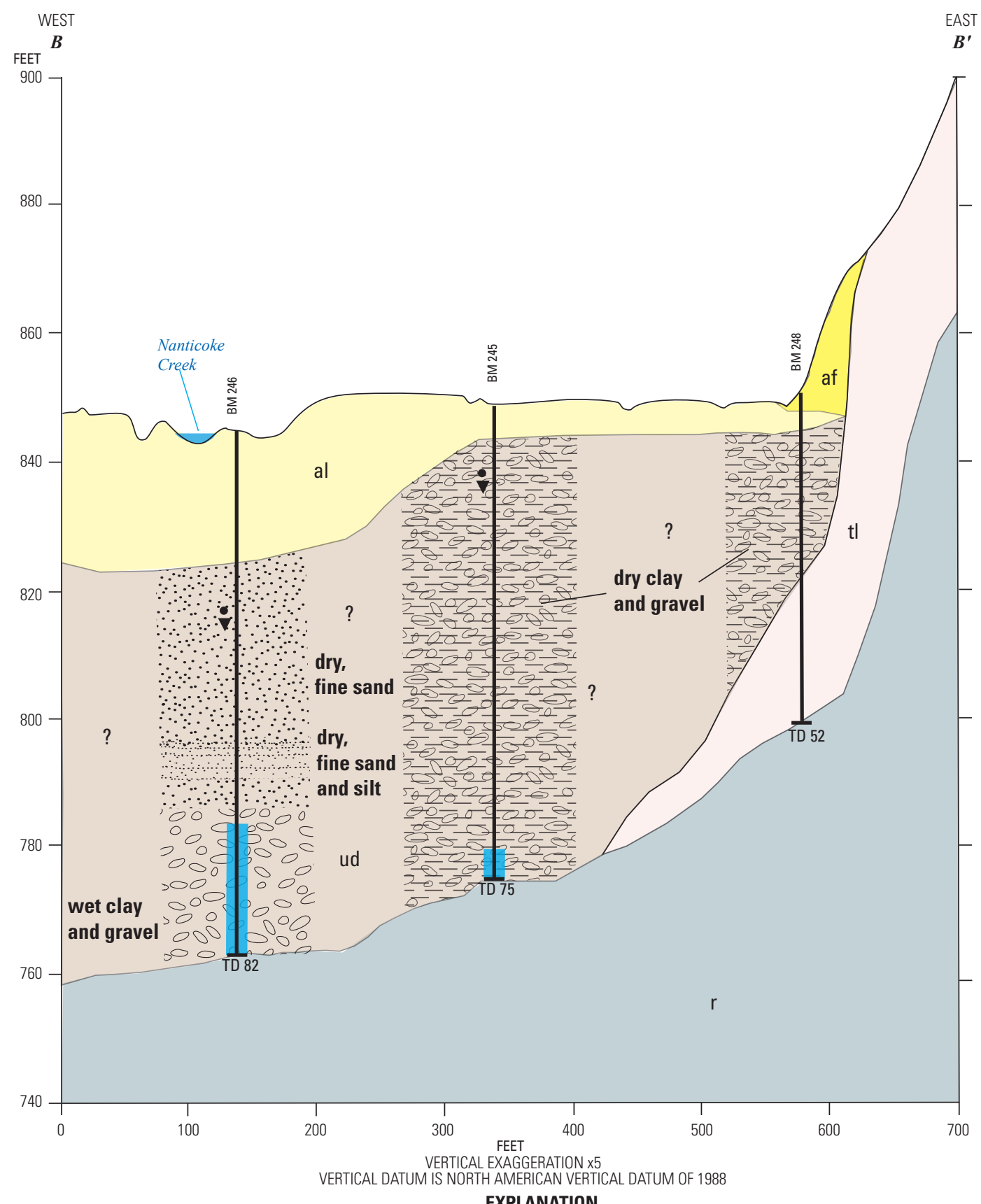

EXPLANATION

Channel and flood-plain alluvium-Gravel, sand, and silt deposited by recent streams. Deposits are found beneath flood plains, on low terraces, and in stream channels

af

Alluvial-fan deposits - Sand and gravel with some silt deposited as fans by upland tributaries where they join the main valley; likely Bradley Creek in this case. May form local unconfined aquifers

ud Undifferentiated material of unknown origin - Buried deposits. Lithology of borehole depicted

Ground-moraine (till) deposits-Consists of subangular to angular clasts (pebbles to boulders) derived in large part from local bedrock that became embedded in a fine-grained matrix consisting of clay, silt, and fine sand $r \quad$ Bedrock-Devonian-age shale, siltstone, and sandstone

BM 246 Well with lithologic log and identifier-Broome County we

1 number (assigned by U.S. Geological Survey), TD and number indicate total depth of well in feet

1 Water source-Source of water likely a confined aquifer. (Note: Driller's terms of wet and dry indicate whether or not materials penetrated are water-yielding; all 'dry' sediments below creek level were saturated)

Geologic Contacts

Accurately to approximately located

??? Unknown

- Water level-Static water level in well

Figure 5. Geologic sections $A-A^{\prime}, B-B^{\prime}$, and $C-C^{\prime}$ in the Nanticoke Creek valley, Broome County, New York. (Section lines shown on figure 4.)—Continued 


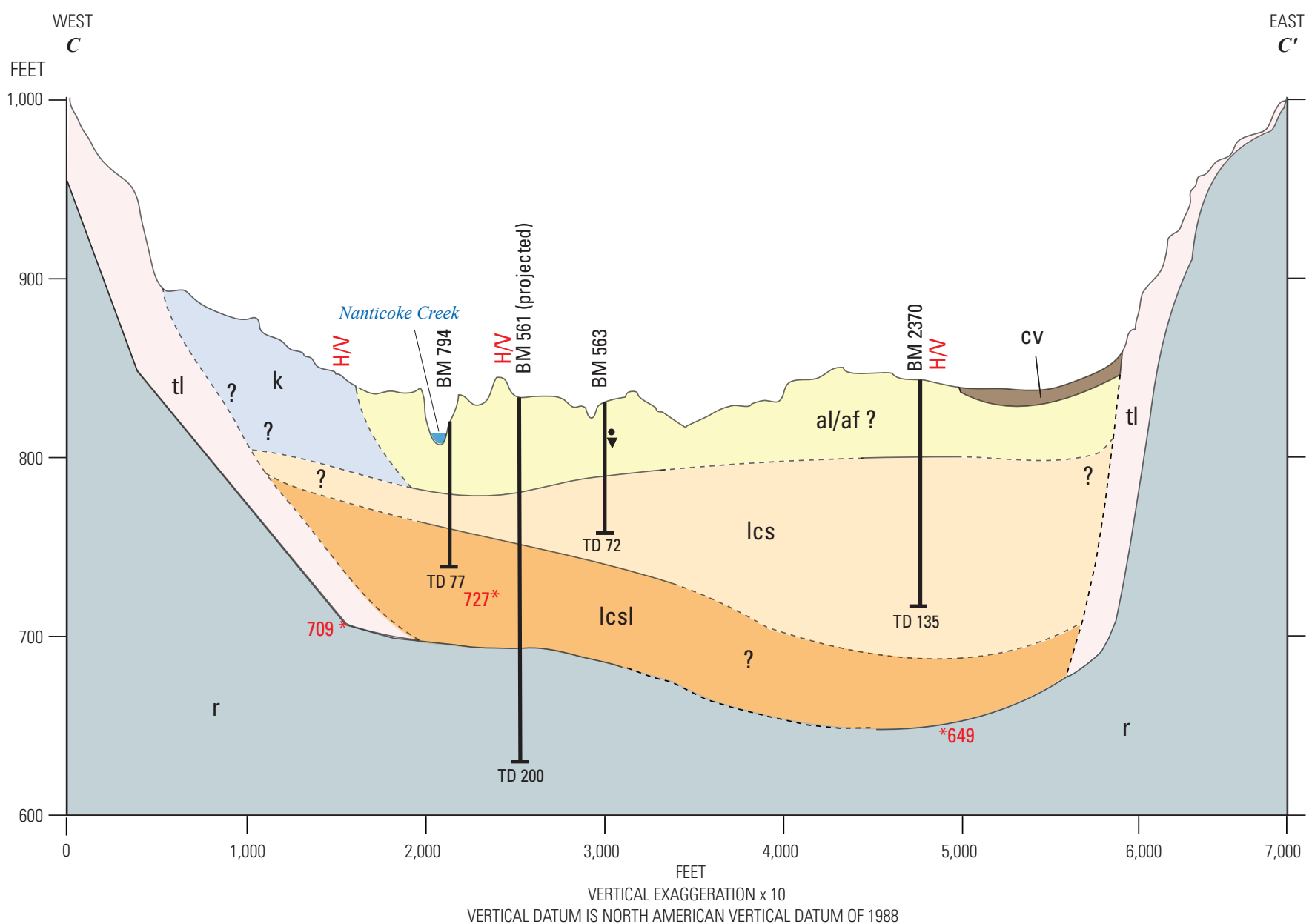

\section{EXPLANATION}

al Channel and flood-plain alluvium - Gravel, sand, and silt deposited by recent streams. Deposits are found beneath flood plains, low terraces, and in stream channels

af Alluvial-fan deposits-Sand and gravel with some silt deposited as fans by upland tributaries where they join the main valley. May form local unconfined aquifers

Ics Clay and sand-Fine-grained sediments that were deposited in former glacial and postglacial lakes; some deposits settled in small, separate basins.

IcsI Clay and silt-Fine-grained sediments that were deposited in former glacial and postglacial lakes; some deposits settled in small, separate basins.

tl

Ground-moraine (till) deposits - Subangular to angular clasts (pebbles to boulders) derived in large part from local bedrock that became embedded in a fine-grained matrix consisting of clay, silt, and fine sand.

$k$ Ice-contact (kame) sand and gravel
CV Urban land-Cut and fill may be composed of well-sorted sand and gravel to poorly sorted gravel, sand, silt, clay, and debris.

$r \quad$ Bedrock-Devonian-age shale, siltstone, and sandstone.

$\geq \quad$ Passive (horizontal-to-vertical ambient-noise) seismic measurement-

플 $\quad$ Asterisk denotes estimated depth to bedrock, elevation noted

BM2222 Well with lithologic log and identifier-Broome County well

$\perp$ number (assigned by U.S. Geological Survey), TD and number indicate total depth of well in feet

Geologic Contacts

_ Accurately to approximately located

Inferred

??? Unknown

- Water level-Static water level in well

Figure 5. Geologic sections $A-A^{\prime}, B-B^{\prime}$, and $C-C^{\prime}$ in the Nanticoke Creek valley, Broome County, New York. (Section lines shown on figure 4.)—Continued 


\section{Glacial Deposits}

The region underwent several major glaciations during the Pleistocene Epoch, commonly referred to as the Ice Age, which began 2.6 million years ago and ended about 12,000 years ago (Fullerton, 1980). Most glacial sediments were deposited as the ice retreated northward between 20,000 and 12,000 years ago (Fullerton, 1980). The unstratified glacial deposits in the study area consists of till (an unsorted mixture of clay, silt, sand, gravel, and rocks) that was deposited in the uplands directly on the bedrock surface by glacial ice. The till is not very permeable and is a poor aquifer, yielding little to no water.

Within the Nanticoke Creek stratified-drift aquifer, unconsolidated deposits consisting of stream-laid sand and gravel, lake-laid silt and clay, post-glacial (alluvial) sand and gravel, and wetland and marsh deposits are present. Coarser-grained sediment (sand and gravel) is the major component of the aquifer generally north of the village of Maine, N.Y., which ranges in thickness from 3 to over $25 \mathrm{ft}$, and in numerous locations the coarse-grained sediment is overlain by extensive wetland deposits. South of Maine to West Corners, N.Y., the aquifer comprises finer-grained silt and clay intermixed with sand and gravel. From West Corners to the Susquehanna River, the bedrock valley becomes deeper and the Nanticoke unconsolidated deposits intermix with those from the Susquehanna River aquifer system.

While a large amount of glacial sediment was deposited in the Nanticoke Creek valley as the ice retreated northward and the glacially-fed streams flowed southward, additional sediment that could have filled the Nanticoke Creek valley was shunted eastward in the west-to-east flowing Dudley Creek valley at Lisle, N.Y., just north of Whitney Point, N.Y. (fig. 1) (Allan Randall, USGS-emeritus, oral commun., May 2013). The prevalence of alluvial fan deposits at the mouths of tributary valleys to Nanticoke Creek indicate that post-glacial erosion of the uplands contributed a large volume of sediment that has accumulated in the valley.

The geologic framework that forms the stratified-drift, or valley fill, aquifer is depicted in several geologic sections at selected locations in the valley (fig. 5, sections $A-A^{\prime}$ through $\left.C-C^{\prime}\right)$.

\section{Hydrogeology}

The stratified-drift aquifer is primarily in the Nanticoke Creek valley but can extend a short distance up into some of the tributary valleys. Of the 96 wells and test holes within the Nanticoke Creek valley used in this study, 78 had records that included location, well depth, and depth to water, and 70 of the 78 additionally had stratigraphic (geologic layering) information (Appendix Data Table 1). Most of these well records were not sufficiently detailed, or the wells were not deep enough, for construction of multiple geologic sections that depict the entire extent or types of the stratified-drift deposits present throughout the Nanticoke Creek valley.

Well records indicate that the northern part of the valley fill aquifer is unconfined and can support the water-supply needs of most homeowners. Unconfined aquifers are open to direct recharge from precipitation and may be influenced by recharge to, or discharge from nearby streams. South of Maine and Union Center, N.Y. (fig. 1), the aquifer materials become less permeable as more lacustrine, fine-grained silt and clay mix with the coarser-grained sand and gravel. In some locations well yields are sufficient for homeowners and small businesses, whereas in an adjacent area the yield can diminish and barely support domestic use because of lower permeability.

\section{Sources of Recharge and Discharge to the Aquifer}

A stratified-drift aquifer can be recharged from three sources: (1) precipitation that falls directly on to the aquifer; (2) upland sources that include (a) tributary streams that lose water to the aquifer where they flow from the bedrock hillside on to alluvial fans in the main valley, and (b) runoff that enters the aquifer along its edges from adjacent hillsides; and (3) groundwater inflow from till and bedrock along the sides and bottom of the aquifer (Randall, 1978). The Nanticoke Creek valley is likely recharged by all of these sources. Local groundwater supply is reliant on these sources, particularly on the valley floor and to a smaller extent by wells on the lower hillsides.

\section{Recharge from Precipitation}

The average annual recharge from direct precipitation over the aquifer is about 14 inches per year (in/yr), as calculated from an average precipitation rate of $33 \mathrm{in} / \mathrm{yr}$ minus an estimated evapotranspiration rate of $19 \mathrm{in} / \mathrm{yr}$ (Kontis and others, 2004, pl. 1; and Randall, 1996). Recharge from precipitation that is not lost through evapotranspiration, or that does not flow overland, is assumed to seep through the soil and into the aquifer. The recharge rate of $14 \mathrm{in} / \mathrm{yr}$ over the surface area of the aquifer (about $5 \mathrm{mi}^{2}$ ) is equivalent to $5.16 \mathrm{ft}^{3} / \mathrm{s}$ or about 3.33 million gallons per day (Mgal/d) of recharge to the aquifer.

\section{Recharge from the Uplands}

The second potential source of recharge to the valleyfill aquifer can be from upland tributaries that may lose water to the aquifer as they flow across an alluvial fan where they enter the main valley before flowing, in this case, to Nanticoke Creek. Streamflow measurements were made on four tributaries on August 7, 2012, during a period of low-flow in the Southern Tier counties of New York, to estimate if these tributaries were losing or gaining (Appendix Data Table 2 at 
http://pubs.usgs.gov/sir/2014/5063/appendix/sir2014-5063 appendix_table1-2.xlsx). The discharge measurements in the tributaries were usually made with the first measurement in a bedrock (headwater) part of the channel, one downstream on unconsolidated (alluvial) deposits and one near the mouth of the tributary before it entered Nanticoke Creek. Results of these measurements indicated that in general, all of the tributaries were losing water from their headwaters but in some cases the stream would lose, then gain, and then become indeterminate at its mouth as streambed aggradation (alluvial deposits of gravel and other debris) left by Tropical Storm Lee the previous fall (September 8-9, 2011) made it impossible to determine the amount of water lost from the stream to the aquifer versus water that flowed within the aggraded alluvial fan and directly to the Creek.

The Ketchumville Branch near Maine, N.Y., appeared to lose flow on a drainage area (per square mile) basis-flow per unit area changed from 0.041 cubic feet per second per square mile $\left(\mathrm{ft}^{3} / \mathrm{s} / \mathrm{mi}^{2}\right)$ in its headwater section to $0.032 \mathrm{ft}^{3} / \mathrm{s} / \mathrm{mi}^{2}$ near the mouth of the stream. Crocker Creek near Union Center had a variable flow regime initially gaining from 0.022 to $0.034 \mathrm{ft}^{3} / \mathrm{s} / \mathrm{mi}^{2}$, then losing about half of its unit-area flow at Route $26\left(0.015 \mathrm{ft}^{3} / \mathrm{s} / \mathrm{mi}^{2}\right)$, but at the mouth, near Nanticoke Creek, there was no discernible flow (however, there was also a large aggraded alluvial fan deposit which was several feet higher than the water level in Nanticoke Creek).

Bradley Creek near Union Center, N.Y., had a unit-area flow of $0.062 \mathrm{ft}^{3} / \mathrm{s} / \mathrm{mi}^{2}$. Further downstream, Bradley Creek's unit-area flow decreased to $0.056 \mathrm{ft}^{3} / \mathrm{s} / \mathrm{mi}^{2}$, but near its mouth, there was no discernible flow in the lower 600 -foot reach of stream channel, and the alluvial fan from Bradley Creek blocked nearly one-third of the channel of Nanticoke Creek just downstream of Union Center. Finally, Day Hollow Creek lost unit-area flow from its headwater area to near Route 26, from 0.020 to $0.010 \mathrm{ft}^{3} / \mathrm{s} / \mathrm{mi}^{2}$, but again, near the mouth of the creek, its alluvial fan was several feet higher than the water level in Nanticoke Creek, and no flow was seen entering the creek, although there may have been flow within the aggraded alluvium that entered Nanticoke Creek.

\section{Recharge from Groundwater}

A minor component of recharge to an unconsolidated valley-fill aquifer is groundwater from the deeper portions of the flow system that discharges into the sides and bottom of the aquifer from the surrounding till and bedrock. This component of groundwater budget in valley-fill aquifers of the glaciated Northeast has not been investigated in detail and is usually a component of the budget that is estimated after the other major components have been derived-A.D. Randall (U.S. Geological Survey, written commun., 2008) suggests that this deep component of the groundwater budget is small or negligible in most cases because shale and till are relatively impermeable, especially at depth.

In the case of Nanticoke Creek, the amount of groundwater entering the aquifer was difficult to measure. One well drilled into bedrock adjacent to the creek at Union Center (BM 785) indicated a water level in the bedrock that was higher than the adjacent stream level, indicating an upward gradient may exist and that at least some groundwater recharge to the stratified-drift aquifer may be from the bedrock. But, while recharge to the aquifer is more likely to occur in some of the tributary stream channels where the distance between bedrock and the land surface is less, the amount of recharge from shale bedrock in any locality is indeterminate and likely quite small.

In evaluating the three discharge measurements made on Nanticoke Creek on July 17, 2012, the stream did appear to gain in unit-area flow between Maine, N.Y. (01513725), and Union Center, N.Y. (01513790), from 0.042 to $0.056 \mathrm{ft}^{3} / \mathrm{s} / \mathrm{mi}^{2}$, but from Union Center to Endicott, N.Y. (01513800), the Creek did not appear to gain much, if any, additional flow $\left(0.058 \mathrm{ft}^{3} / \mathrm{s} / \mathrm{mi}^{2}\right)$ at Endicott, N.Y. This condition is likely due to (1) the tighter-grained valley-fill deposits found in the lower part of the creek that may impede upward discharge from the bedrock to the aquifer, (2) the greater distance from bedrock to land surface, (3) possible underflow to the deeper part of the Susquehanna River aquifer, and (4) the influence of the Endicott water supply wells further to the southeast and two purge wells near the former Endicott landfill to the southwest, all of which withdraw large amounts of groundwater in the Susquehanna aquifer system (fig. 2-see the hachured area near the Susquehanna River).

\section{Groundwater Levels}

Synoptic groundwater level measurements were collected on October 17, 2012, from 21 wells between Glen Aubrey and West Corners, N.Y. (fig. 2). While the wells were completed in both unconsolidated materials and bedrock, the resulting water levels are a good indication of the groundwater table in and adjacent to the valley-fill aquifer on that day. Where data were sparse, especially in tributary valleys, groundwater elevations were extrapolated where streams crossed specific topographic elevations. The slope of the water table follows the general slope of the valley floor and therefore, groundwater flows from north to south in the stratified-drift aquifer in the Nanticoke Creek valley, with an average water-table gradient of $15 \mathrm{ft} / \mathrm{mi}$ (fig. 2).

Groundwater levels were also continuously measured in three wells between Maine and West Corners, N.Y., two wells in unconsolidated materials (BM 778 and BM 787) and one in bedrock (BM 785 on fig. 2). The water level of Nanticoke Creek at Union Center, N.Y. (01513790), was also measured to determine any relationship between groundwater levels in well BM 785 and the creek, and daily precipitation data were available from the Binghamton Regional Airport located just east of the Nanticoke Creek watershed (fig. 1). The water level in each well and Nanticoke Creek was recorded every four hours and the hydrographs for these three wells and Nanticoke Creek at Union Center are shown on figure 6. 
Well BM 785, water level in bedrock at Union Center, New York

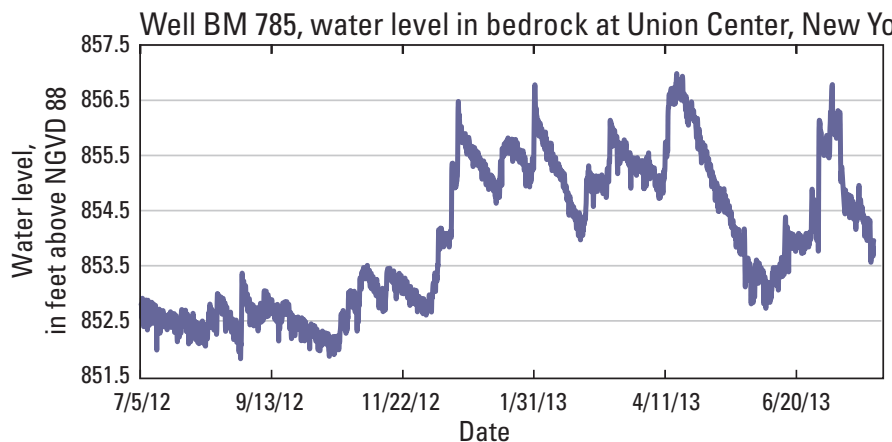

Well BM 778, water level in stratified-drift deposits near

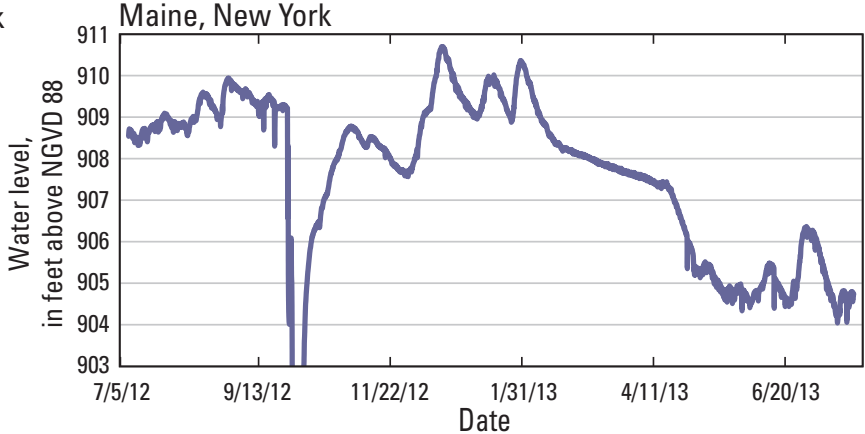

Daily precipitation at Binghamton Regional Airport near Maine, New York
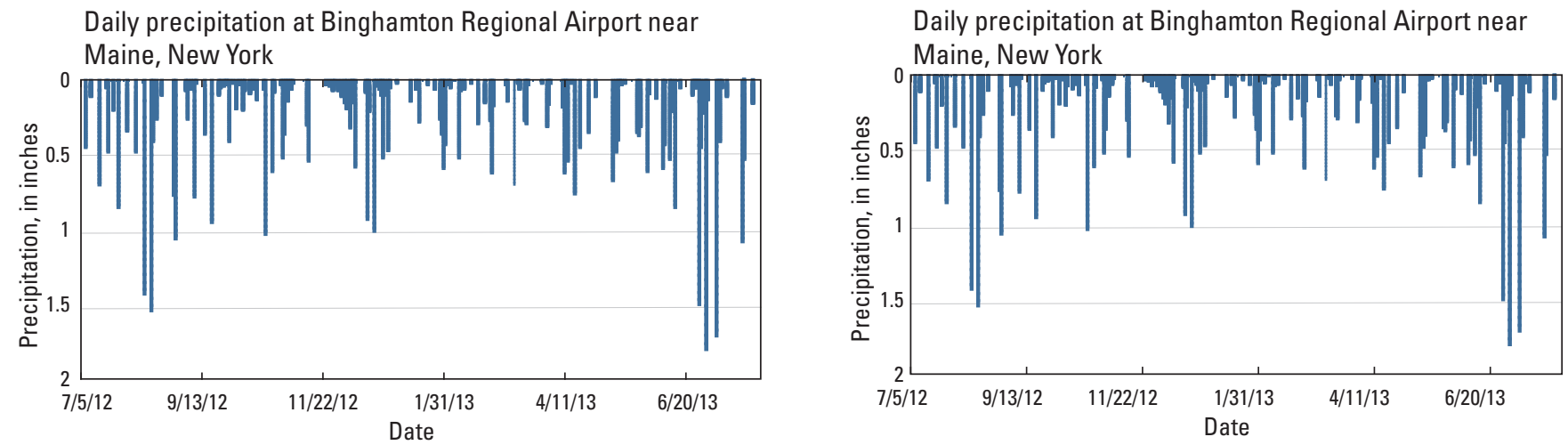

Water level in Nanticoke Creek near Union Center,

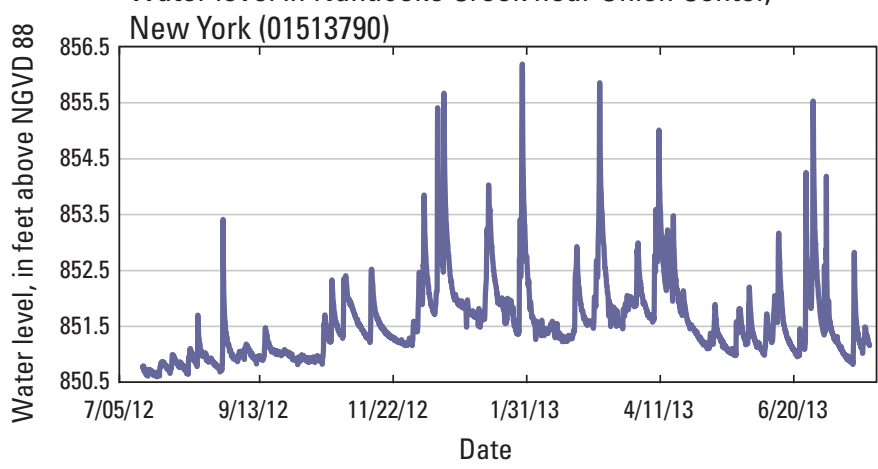

Well BM 787, water level in stratified-drift deposits near

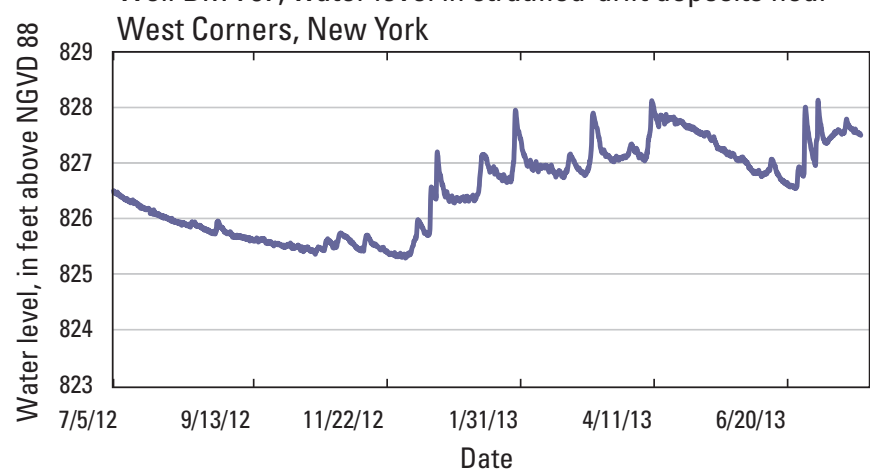

Figure 6. Monitored groundwater levels in the Nanticoke Creek stratified-drift aquifer, water levels in Nanticoke Creek at Union Center, New York, and daily precipitation from the Binghamton Regional airport, July 2012 to July 2013. 
The water levels in all the monitoring wells (BM 778Maine, N.Y., BM 785-Union Center, N.Y., and BM 787-north of West Corners, N.Y.-fig. 2) appear to respond to aquifer recharge beginning in the late fall/early winter period but not to shorter-term fluctuations in the water level of Nanticoke Creek nor in the case of BM 778, to a tributary to Nanticoke Creek that is located just west of this well. A large decline in water level of BM 778 (approximately $14 \mathrm{ft}$ ) and its slow recovery during the late fall of 2012 may have been due to a nearby water-supply well (BM2222) at the school bus garage having been "left on" during a long vacation weekend (Mike Aubel, Maine-Endwell bus garage, oral commun., December 2012). This continuous discharge from BM2222 appears to have affected the water level in the monitoring well BM 778 as the two wells are only $30 \mathrm{ft}$ apart, although open to the aquifer at different depths and units-BM 778 is finished in sand and gravel and is an open-ended casing completed at $140 \mathrm{ft}$, while BM2222 is completed in bedrock between 171-190 ft. Well BM 778 slowly recovered over an approximate 35-day period, even though water levels at the other monitoring wells were steady or still slowly declining even with some appreciable precipitation falling during this period (see fig. 6-Binghamton Regional Airport, daily precipitation data).

Well BM 785 is adjacent to Nanticoke Creek (fig. 2) and is completed in bedrock. Comparison of the well and stream hydrographs (fig. 6) indicate an upward gradient between the bedrock and the Nanticoke Creek stratified-drift aquifer in this location. The gradient is greatest in the spring recharge period, although the water level in well BM 785 does not appear to be strongly related to stream level fluctuations in Nanticoke Creek. The finer-grained materials found in the southern part of the Nanticoke Creek valley likely prevent a strong connection between the creek, the aquifer, and the deeper, underlying bedrock in this part of the Nanticoke Creek valley.

\section{Water Quality}

Water-quality samples were collected to characterize the chemical quality of surface water and groundwater in the Nanticoke Creek valley. Three water-quality samples were collected along Nanticoke Creek and one on Bradley Creek on July 17, 2012. Three groundwater samples were collected from private drinking water wells, two finished in unconsolidated deposits and one in bedrock on November 19, 2012. Field measurements were made for $\mathrm{pH}$, specific conductance, and water temperature for surface-water and groundwater samples. The concentrations of over 40 constituents in surface-water and groundwater samples were measured, including major inorganic ions, nutrients, trace metals, and dissolved gases (Appendix Data Table 3 at http://pubs.usgs.gov/sir/2014/5063/ appendix/sir2014-5063_appendix_table1-3.xlsx). All samples were analyzed by USGS laboratories in Denver, Colorado, or Reston, Virginia. Analytical results for selected constituents are compared with Federal and State drinking-water standards, which include Maximum Contaminant Levels (MCLs), secondary maximum contaminant levels (SMCLs), and health advisories (HAs) established by the U.S. Environmental Protection Agency (U.S. Environmental Protection Agency, 2011) and the New York State Health Department (New York State Department of Health, 2013).

Additional water-quality data are also available from several other sources for the Nanticoke Creek valley: (1) historic water-quality data for several stream sites in the valley from the USGS NWIS database (Appendix Data Table 4 at http://pubs.usgs.gov/sir/2014/5063/appendix/ sir2014-5063_appendix_table1-4.xlsx), (2) the Susquehanna River Basin Commission maintains a streamgage on Nanticoke Creek near Maine, N.Y., and has both real-time water-quality data (http://mdw.srbc.net/remotewaterquality/ data_viewer.aspx), as well as bi-monthly water-quality measurements (Appendix Data Table 5 at http://pubs.usgs.gov/ sir/2014/5063/appendix/sir2014-5063_appendix_table1-5. $x l s x$ ), and (3) water-quality data collected at a greenhouse supply well over several decades and adjacent residential well (Appendix Data Table 6 at http://pubs.usgs.gov/sir/2014/5063/ appendix/sir2014-5063_appendix_table1-6.xlsx).

\section{Physiochemical Properties}

The $\mathrm{pH}$ of surface-water and groundwater samples collected by the USGS during this study ( 7 samples) ranged from 7.1 to 8.0 , with a median value of 7.8 and all samples were within the accepted EPA SMCL range of 6.5 to 8.5 (U.S. Environmental Protection Agency, 2011). Specific conductance of all but one sample ranged from 256 to 576 microsiemens per centimeter $(\mu \mathrm{S} / \mathrm{cm})$ at $25^{\circ} \mathrm{C}$. Well BM 501, a 40-foot deep dug well, had a conductance of $1,200 \mu \mathrm{S} / \mathrm{cm}$ at $25^{\circ} \mathrm{C}$; this value was possibly related to the influence of road salt because the well is near State Route 26 and a steep hillside road. This well also exhibited many of the highest ion concentrations of the wells sampled during this study. Of note, several wells had a distinct smell of hydrogen sulfide during groundwater level data collection, and one of the sampled wells (BM 502) had a hydrogen sulfide smell when that sample was collected.

\section{Common Inorganic Constituents}

Cation concentrations include calcium, ranging from 24.5 to 93.7 milligrams per liter $(\mathrm{mg} / \mathrm{L})$, and a median value of $29.7 \mathrm{mg} / \mathrm{L}$ as well as magnesium concentrations ranging from 4.98 to $26.7 \mathrm{mg} / \mathrm{L}$, and a median of $5.66 \mathrm{mg} / \mathrm{L}$. While calcium and magnesium can contribute to water hardness, it should be noted that the stream samples generally had lower calcium and magnesium concentrations than the groundwater samples. Sodium concentrations ranged from 13.0 to $105 \mathrm{mg} / \mathrm{L}$, with a median value of $25.9 \mathrm{mg} / \mathrm{L}$. Potassium concentrations ranged from 0.631 to $2.240 \mathrm{mg} / \mathrm{L}$, with a median value of $1.680 \mathrm{mg} / \mathrm{L}$.

Anion concentrations include chloride ranging from 8.90 to $265 \mathrm{mg} / \mathrm{L}$, and a median value of $48.3 \mathrm{mg} / \mathrm{L}$. Sulfate 
concentrations ranged from 8.22 to $35.9 \mathrm{mg} / \mathrm{L}$, with a median value of $11.6 \mathrm{mg} / \mathrm{L}$. Silica concentrations ranged from 2.56 to $14.9 \mathrm{mg} / \mathrm{L}$, with a median value of $4.03 \mathrm{mg} / \mathrm{L}$. Fluoride concentrations ranged from the detection limit of 0.044 to $0.106 \mathrm{mg} / \mathrm{L}$ with a median of $0.075 \mathrm{mg} / \mathrm{L}$. Of all of the major inorganic constituents collected from surface-water and groundwater sites in the study area, only well BM 501 exceeded the chloride and sodium Federal and State waterquality standards for these constituents, and may be due to road salt contamination from two nearby roads.

\section{Nutrients}

Nitrate was present in some surface water and groundwater samples and ranged from $<0.040$ to $3.08 \mathrm{mg} / \mathrm{L}$ as nitrogen, with a median value of $0.148 \mathrm{mg} / \mathrm{L}$. High concentrations of nitrogen can cause excessive plant and algal growth in streams, and can also be a human health concern when the concentration is more than $10 \mathrm{mg} / \mathrm{L}$ as nitrogen (U.S. Environmental Protection Agency, 2011). However, the concentration of nitrate in the streams is low and the highest value was in a groundwater well (BM 501). Four of the seven orthophosphate concentrations were below the reporting limit $(0.0040 \mathrm{mg} / \mathrm{L}$ as phosphorus) while for the remaining three samples (one surface water site [01513792 Bradley Creek] and two groundwater wells [BM 501 and BM2283]) ranged between 0.0090 and $0.0551 \mathrm{mg} / \mathrm{L}$ - there are no drinking water standards for orthophosphate. None of the water-quality samples exceeded Federal or State drinking-water standards for nitrate or nitrite.

\section{Trace Elements}

Trace elements were detected in all the water samples which included aluminum, antimony, arsenic, barium, boron, cadmium, chromium, cobalt, copper, iron, lead, lithium, manganese, molybdenum, nickel, selenium, strontium, uranium, vanadium, and zinc (Appendix Data Table 3). The trace elements detected in the greatest concentrations were aluminum, barium, boron, iron, lithium, manganese, and strontium. No samples exceeded Federal or State Maximum Contaminant Loads (MCLs) except for manganese. Aluminum concentrations ranged from less than the detection limit of 2.2 to 5.6 micrograms per liter $(\mu \mathrm{g} / \mathrm{L})$, with a median value of $2.4 \mu \mathrm{g} / \mathrm{L}$. Arsenic concentrations ranged from 0.090 to $2.37 \mu \mathrm{g} / \mathrm{L}$, with a median of $0.560 \mu \mathrm{g} / \mathrm{L}$. Barium concentrations ranged from 9.17 to $967 \mu \mathrm{g} / \mathrm{L}$, with a median of $63.1 \mu \mathrm{g} / \mathrm{L}$. Boron concentrations ranged from 15.0 to $28.8 \mu \mathrm{g} / \mathrm{L}$, with a median of $19.0 \mu \mathrm{g} / \mathrm{L}$. An MCL has not been established for boron. Iron concentrations ranged from 6.00 to $138 \mu \mathrm{g} / \mathrm{L}$, with a median of $51.0 \mu \mathrm{g} / \mathrm{L}$. Lead concentrations ranged from less than the detection limit of 0.025 to $0.675 \mu \mathrm{g} / \mathrm{L}$, all of which are well below the EPA MCL of $15.0 \mu \mathrm{g} / \mathrm{L}$. Lithium concentrations ranged from 0.22 to $24.4 \mu \mathrm{g} / \mathrm{L}$, with a median value of $6.09 \mu \mathrm{g} / \mathrm{L}$. An MCL has not been established for lithium. Strontium concentrations ranged from 42.0 to $711 \mu \mathrm{g} / \mathrm{L}$, with a median of $104 \mu \mathrm{g} / \mathrm{L}$. An MCL has not been established for strontium. Uranium concentrations ranged from less than the detection limit of 0.004 to $1.290 \mu \mathrm{g} / \mathrm{L}$, with a median of $0.125 \mu \mathrm{g} / \mathrm{L}$. No samples exceeded the EPA MCL of $30 \mu \mathrm{g} / \mathrm{L}$.

Manganese concentrations ranged between 0.067 and $660 \mu \mathrm{g} / \mathrm{L}$ with a median of $16.0 \mu \mathrm{g} / \mathrm{L}$. The EPA Secondary MCL for manganese is $50 \mu \mathrm{g} / \mathrm{L}$, whereas the New York State Health Departments MCL is $300 \mu \mathrm{g} / \mathrm{L}$. The highest manganese concentrations in this study were found in wells BM2283 and BM 502 and manganese was also elevated in Nanticoke Creek at Endicott, N.Y. (01513800). These relatively large manganese concentrations ( 328 and $660 \mu \mathrm{g} / \mathrm{L}$ ) in groundwater and $213 \mu \mathrm{g} / \mathrm{L}$ in Nanticoke Creek, while above the State and Federal drinking water standards, are not that unusual in the region based on results of groundwater samples collected across New York as part of the cooperative New York State Department of Environmental Conservation and USGS 305B groundwater monitoring program (http://ny.water.usgs.gov/ projects $/ 305 \mathrm{~b} /$ ). The likely source of the manganese is from the surrounding shale bedrock and the stratified-drift materials that partly fill the Nanticoke Creek valley that are derived from the local bedrock.

In all other cases, the chemistry of surface water and groundwater is well within State and Federal standards in the Nanticoke Creek valley. It is interesting to note that some of the older water-quality data for streams (late 1950s through mid-1970s) (Appendix Data Table 4) have lower ion concentrations then those measured presently. The increased chloride, sodium, and dissolved solids values measured in this study are likely indicative of road salt runoff to the aquifer (Kappel and others, 2012). Nutrient analysis results for nitrogen and phosphorus species indicate little in the way of anthropogenic influences on either surface water or groundwater.

\section{Dissolved Methane}

Dissolved gases were analyzed in groundwater to establish a baseline of methane in the stratified-drift aquifer system. The three groundwater samples in this study (BM 501, 502, and 2283-Appendix Data Table 2) ranged from non-detect $(<0.001 \mathrm{mg} / \mathrm{L})$ to $0.55 \mathrm{mg} / \mathrm{L}$ of dissolved methane. During the summer of 2012, dissolved gas samples throughout the southern tier counties of New York were collected for a separate USGS study to establish a regionwide dissolved methane baseline. Two samples were collected within the Nanticoke Creek valley —one in a well drilled into unconsolidated sediments (BM1049) that had a dissolved methane concentration of $0.005 \mathrm{mg} / \mathrm{L}$ and the other well was drilled into bedrock (BM2222) and had a dissolved methane concentration of $9.6 \mathrm{mg} / \mathrm{L}$. All five of these dissolved methane values are well below the potentially explosive limit of $28 \mathrm{mg} / \mathrm{L}$ dissolved methane (Eltschlager and others, 2001, p. 40). 


\section{Summary}

The Village of Endicott, New York, is looking for an alternate source of public drinking water that could supplement their current supply which is affected by legacy contamination. The Nanticoke Creek valley, which drains southward toward the village, was identified by the village as a potential water-supply source, and the local stratifieddrift (valley-fill) aquifer was investigated to determine its hydrogeologic and water-quality characteristics through this study. The Nanticoke Creek stratified-drift aquifer extends about 15 miles from the hamlet of Glen Aubrey, N.Y., to near West Corners, N.Y., just north of the village. Nanticoke Creek flows southward through the hamlets of Maine, Union Center, and West Corners, N.Y., and eventually to the Susquehanna River at Endicott, N.Y. The Nanticoke Creek valley floor is less than a half mile wide in most places. The glacial sediments that comprise the valley fill vary from 3 to over 25 feet of permeable sand and gravel in the northern part of the aquifer to less permeable sand and gravel mixed with fine-grained silt and clay toward the southern end. The entire valley is underlain by poorly permeable Devonian-aged shale and siltstone and is usually capped with glacial till in the uplands, on side slopes of the valley, and along the floor of the bedrock valley.

The availability of groundwater to individual wells from the unconsolidated aquifer in the stratified-drift aquifer is variable, but is enough to supply most homeowner wells, and in some cases has enough water to supply small publicwater systems such as schools, mobile-home parks, and small commercial/industrial facilities. Groundwater availability is better in the northern part of the aquifer where sand and gravel deposits are generally more permeable than in the southern half of the valley where finer-grained sediments settled out with the alluvial sand and gravel creating less-permeable aquifer material.

The flow in Nanticoke Creek is driven by precipitationderived runoff and recharge to and from the groundwater system. Tropical Storm Lee (fall, 2011) caused the worst flood on record in the Southern Tier counties of New York, whereas during the summer of 2012, near record low-flows were experienced in the Southern Tier counties of New York, including the Nanticoke Creek valley. Most tributary streams appear to lose water to the alluvial deposits as they flow off of their bedrock-lined channels to alluvial fans and valley-bottom floodplain deposits. Extensive sediment aggradation near the mouths of the tributary streams draining to Nanticoke Creek due to Tropical Storm Lee made it impossible to determine the amount of tributary loss or gain in the lower part of these channels near Nanticoke Creek.

The quality of both surface water and groundwater is good, although certain natural constituents (manganese and iron) have been detected in groundwater and surface water, while home-owner reported smell and taste of hydrogen sulfide from some wells have been reported. The water-quality analysis of both surface water and groundwater indicated that both sources of water met nearly all State and Federal water-quality standards. Two well samples and one surface water sample exceeded the State and Federal standards for manganese, but these manganese concentrations are not that unusual for waters sourced in either shale bedrock or in glacial sediments derived from these rocks in central New York. Sodium and chloride standards were exceeded in one well that may be influenced by road salt runoff from nearby roads. Dissolved methane concentrations from five wells were all well below the potentially explosive limit for dissolved methane (28 milligrams per liter).

\section{References Cited}

Brown, R.H., and Ferris, J.G., 1946, Progress report on ground-water resource of the southwestern part of Broome County, New York: Prepared in cooperation with the New York Water Power and Control Commission, $92 \mathrm{p}$.

Eltschlager, K.K., Hawkins, J.W., Ehler, W.C., and Baldassare, Fred, 2001, Technical measures for the investigation and mitigation of fugitive methane hazards in areas of coal mining: Office of Surface Mining Reclamation and Enforcement, $125 \mathrm{p}$.

Fullerton, D.S., 1980, Preliminary correlation of post-Erie interstadial events $(16,000-10,000$ radiocarbon years before present) central and eastern Great Lakes region, and Hudson, Champlain, and St. Lawrence lowlands, United States and Canada: U.S. Geological Survey Professional Paper 1089, $52 \mathrm{p}$.

Kappel, W.M., Sinclair, G.J., Reddy, J.E., Eckhardt, D.A., deVries, M.P., and Phillips, M.E., 2012, Specific conductance measurements in central and western New York streams-A retrospective characterization: U.S. Geological Survey Open-File Report 2012-1174, 6 p. (Also available at $h t t p: / / p u b s . u s g s . g o v / o f / 2012 / 1174 /$.)

Kontis, A.L., Randall, A.D., and Mazzaferro, D.L., 2004, Regional hydrology and simulation of flow of stratified-drift aquifers in the glaciated northeastern United States: U.S. Geological Survey Professional Paper 1415-C, 156 p.

Lane, J.W., Jr., White, E.A., Steele, G.V., and Cannia, J.C., 2008 , Estimation of bedrock depth using the horizontalto-vertical (H/V) ambient-noise seismic method, in Symposium on the Application of Geophysics to Engineering and Environmental Problems, April 6-10, 2008, Philadelphia, Pennsylvania, Proceedings: Denver, Colo., Environmental and Engineering Geophysical Society, $13 \mathrm{p}$. 
Martin, R.J., and Shumaker, V.O., 1968, Development of water facilities_-Broome County 1967-2017: Board of Supervisors of Broome County and New York State Health Department, Project number CPWS-8, 103 p., 4 appendixes.

Muller, E.H., and Cadwell, D.H., 1986, Surficial geologic map of New York: New York State Museum-Geological Survey, Map and Chart Series 40, Finger Lakes Sheet, New York State Geological Survey, scale 1:250,000.

New York State Department of Health, 2013, Part 5, Sub-part 5-1 Public Water Systems-Tables of Maximum Contaminant Levels, accessed March 2013, at https://www.health.ny.gov/regulations/nycrr/title_10/part_5/ subpart_5-1_tables.htm.

Randall, A.D., 1972, Records of wells and test borings in the Susquehanna River basin, New York: New York State Department of Environmental Conservation Bulletin 69, $92 \mathrm{p}$.

Randall, A.D., 1978, Infiltration from tributary streams in the Susquehanna River basin: U.S. Geological Survey Journal of Research, v. 6, no. 3, p. 285-297.

Randall, A.D., 1996, Mean annual runoff, precipitation, and evapotranspiration in the glaciated northeastern United States, 1951-80: U.S. Geological Survey Open-File Report 96-395, 2 pls.

Rantz, S.E., and others, 1982, Measurement and computation of streamflow: U.S. Geological Survey Water-Supply Paper 2175, v. 2, 631 p.
Rickard, L.V., and Fisher, D.W., 1970, Geologic map of New York, Finger Lakes sheet: New York State Museum and Science Service, Map and Chart Series No. 15, scale $1: 250,000$.

U.S. Department of Agriculture, 2008, SSURGO digital soil-survey data, accessed October 30, 2012, at http://soildatamart.nrcs.usda.gov.

U.S. Environmental Protection Agency, 2011, 2011 edition of the drinking water standards and health advisories, EPA 820-R-11-002, 12 p., accessed March 2013, at http://water.epa.gov/action/advisories/drinking/upload/ dwstandards2011.pdf.

U.S. Geological Survey, 2013a, National Water Quality Laboratory: U.S. Geological Survey, accessed January 2013, at http://nwql.usgs.gov/.

U.S. Geological Survey, 2013b, Analytical procedures for dissolved gas: U.S. Geological Survey accessed January 2013, at http://water.usgs.gov/lab/dissolved-gas/ lab/analytical procedures/.

U.S. Geological Survey, 2013c, USGS water data for New York: U.S. Geological Survey, accessed January 2013, at http://waterdata.usgs.gov/ny/nwis.

U.S. Geological Survey, [variously dated], National field manual for the collection of water-quality data: U.S. Geological Survey Techniques of Water-Resources Investigations, book 9, chap. A1-A9, accessed December 5, 2012, at http://pubs.water.usgs.gov/twri9A/. 

Appendix 1. Record of Wells and Test Holes Used in the Nanticoke Creek Stratified-Drift Aquifer Study, Broome County, New York

[Available separately at http://pubs.usgs.gov/sir/2014/5063/]

Appendix 2. Results of Seepage Measurements and Subbasin Data for Nanticoke Creek and its Major Tributaries, Broome County, New York

[Available separately at http://pubs.usgs.gov/sir/2014/5063/]

Appendix 3. Water-Quality Data for Four Surface-Water Sites and Three Groundwater Wells in the Nanticoke Creek Valley, Broome County, New York

[Available separately at $h t t p: / / p u b s . u s g s . g o v / s i r / 2014 / 5063 /]$

Appendix 4. Historic Water-Quality Data for Nanticoke Creek, Broome County, New York

[Available separately at http://pubs.usgs.gov/sir/2014/5063]

Appendix 5. Susquehanna River Basin Commission RealTime and Periodic Water-Quality Data for Nanticoke Creek near Maine, New York

[Available separately at http://pubs.usgs.gov/sir/2014/5063]

Appendix 6. Water-Quality Data from a Greenhouse Supply Well, 1991, 2001, and 2011, and a Residential House Well, 2011, near Union Center, New York 
Prepared by the Pembroke and Rolla Publishing Service Centers.

For additional information write to:

New York Water Science Center

U.S. Geological Survey

30 Brown Rd.

Ithaca, NY 14850

Information requests:

(518) 285-5602

or visit our Web site at:

http://ny.water.usgs.gov 
